\title{
Emission and Neutralization of Methane from a Municipal Landfill-Parametric Analysis
}

\author{
Józef Ciuła ${ }^{1}$, Violetta Kozik ${ }^{2, *}$, Agnieszka Generowicz ${ }^{3, *}{ }^{\circledR}$, Krzysztof Gaska ${ }^{4}{ }^{\oplus}$, \\ Andrzej Bak ${ }^{2}$, Marlena Paździor ${ }^{2}$ and Krzysztof Barbusiński 4 (D) \\ 1 Institute of Engineering, State University of Applied Sciences, Nowy Sacz, Zamenhofa 1A, \\ 33-300 Nowy Sacz, Poland; jciula@pwsz-ns.edu.pl \\ 2 Institute of Chemistry, University of Silesia in Katowice, Szkolna 9, 40-007 Katowice, Poland; \\ andrzej.bak@us.edu.pl (A.B.); marlena.pazdzior@us.edu.pl (M.P.) \\ 3 Department of Environmental Technologies, Cracow University of Technology, Warszawska 24, \\ 31-155 Cracow, Poland \\ 4 Department of Water and Wastewater Engineering, Silesian University of Technology, Konarskiego 18, \\ 44-100 Gliwice, Poland; krzysztof.gaska@polsl.pl (K.G.); krzysztof.barbusinski@polsl.pl (K.B.) \\ * Correspondence: violetta.kozik@us.edu.pl (V.K.); agenerowicz@pk.edu.pl (A.G.); \\ Tel.: +48-032-359-1336 (V.K.); +48-012-628-2183 (A.G.)
}

Received: 30 October 2020; Accepted: 25 November 2020; Published: 27 November 2020

\begin{abstract}
An attempt was made to estimate the annual production of $\mathrm{CH}_{4}$ at a municipal waste landfill site in Poland. As a matter of fact, the extent of the unorganized emission of $\mathrm{CH}_{4}$ from the landfill surface was approached based on the adopted mathematical model. The Ward agglomeration method for cluster analysis and the Pearson coefficient were employed to evaluate the distance-based similarity measure and to optimize methods for estimating methane emissions from a landfill as well as to verify the input parameters for the model. In order to calculate the content of biodegradable organic parts in the waste, morphological tests of the landfilled waste were performed. Physical quantities, measurements and the actual amount of the landfilled waste as well as the volume of $\mathrm{CH}_{4}$ neutralized in a collective flare were implemented in the model, respectively. The model-based findings and experimental outcome demonstrated stable gas production in the landfill with a high $\mathrm{CH}_{4}$ content. On the other hand, a rather low efficiency of the landfill passive degassing installation indicated the necessity to design and develop its active counterpart with the prospective application of the generated biogas for energy production in a cogeneration system.
\end{abstract}

Keywords: renewable energy; landfill gas; degassing installation; municipal waste; landfill site; cogeneration

\section{Introduction}

In the last decade, approximately 2 billion people were deprived of waste collection services worldwide. Moreover, nearly 3 billion Earth inhabitants have no access to controlled waste disposal facilities. Unfortunately, it is expected that the waste-related issues will only worsen in line with urbanization growth, income rise and consumer-oriented economy expansion, especially in developing countries. Within the next 30 years, the overall amount of waste produced globally is foreseen to double from nearly 2 billion metric tons in 2016 [1]. Waste generation has been an inherent feature of human economic activity over the centuries, while its management is becoming a major problem for many societies and economies. The necessity of waste management results from the need to reduce the space indispensable for their neutralization/processing/storage and subsequently the protection of environmental resources. The generated wastes should be segregated and recycled including 
the recovery of energy in the fermentation process of biodegradable waste-e.g., such as green waste and food [2,3]. In recent years, sequencing batch reactors (SBRs) are becoming more and more popular in the wastewater treatment due to their working flexibility and adaptability to the variable quality of raw wastewater [4]. Following European Union (EU) regulations, the priority of introducing a general obligation to separate biodegradable waste at the source, including households, restaurants and supermarkets, has been noticed. The waste separation procedures allow to extract such wastes from the mixed mainstream of waste passed to the landfill. It seems that a clean waste stream can be used as input material for the fermentation process and the subsequent production of biogas as an energy carrier [5-7]. Biowaste fermentation processes are also possible to implement without a centralized system-for instance, in rural areas, contributing to the energy needs of the local communities. Such a solution can improve the living standard of the inhabitants as well as reduce energy consumption [8]. In fact, the generation and disposal of municipal waste is becoming a progressively significant environmental, economic and social issue. It was scientifically confirmed that the mass of generated waste per capita is growing with the rise of economic growth, especially in developing countries [9]. The bioeconomy concentrates on the implementation of biomass/biowaste in fundamental production branches (e.g., agriculture, forestry, fisheries) and relevant valorization of raw materials. Undoubtedly, biomass processing can facilitate to accomplish the EU's renewable energy goals. Obviously, a noticeable linkage between the bioeconomy, circular economy, bioproducts, and bioenergy is observed globally [10]. Despite the applied segregation systems, municipal waste contains organic fractions with high energy potential for the bioeconomy [11]. On the other hand, the limited time and funding can hamper the achievement of the ambitious sustainable development objectives in mitigating climate changes. Hence, the use of the two-tier multi-criteria decision analysis (MCDA) seems beneficial in order to identify the promising bio-based value chains that are valid to the EU bioeconomy plans [12]. In many countries, the storage of municipal solid waste (MSW) in landfills is still the primary method of disposal. Hence, the EU has imposed restrictions on storage of biodegradable waste as well as the waste with a specific energy value on landfills_-only residual wastes that cannot be used in any recycling processes are allowed to be stored. In reality, not only significant amounts of organic fractions are retained, but also wastes bearing signs of industrial waste. The wastes generated by mechanical treatment (having the energy value above $6 \mathrm{MJ} / \mathrm{kg}$ ) can be potentially recycled with the generation of waste-based fuel [13-15]. As a matter of fact, there was no political will to reduce or prevent the waste production in the EU countries in the past-common practice was passing them to landfills. In the absence of appropriate policies, the deposition of the prevailing part of the municipal waste stream in landfills was affected by the growing costs incurred by the use of alternative methods [16].

The research performed on closed landfills indicated the presence of an increased content of polycyclic aromatic hydrocarbons (PAHs) and other organic compounds that contaminate the nearby groundwater. The noticeable relationship between the content of ammonium nitrogen in surface/groundwater and the increment in the concentration of $\mathrm{NH}_{4}-\mathrm{N}$ might suggest that landfill leachate can pollute the surrounding environment considerably [17]. In fact, heavy metals and other chemical compounds can migrate to the ground or surface water as a result of inappropriate sewage management or unintended installation breakdowns in a landfill, which pose a real threat to human health and life. Moreover, the operational problems in technological processes of water treatment at water intakes can endanger the quality of water overall $[18,19]$. In addition, the susceptibility of groundwater to contamination is higher the closer the river basin area is to the examined facility. Not surprisingly, this is correlated with the geological features and structure of a given area. In fact, a number of highly permeable formations grow in the phreatic zone, which negatively affects the class of groundwater-areas with high susceptibility to anthropogenic influence (including landfills) should be treated as high priority [20].

The uncontrolled emissions of landfill gas (LFG) to the air is another landfill-related threat to the nature exerted by municipal waste composed of the biodegradable fractions. On the whole, 
rational water management and rational waste management are important mitigation and adaptation strategies in the circular economy era in order to counter climate change [21].

On the other hand, the increasing public awareness of human health hazards is among the major driving forces to reduce the LFG generation-mainly $\mathrm{CH}_{4}, \mathrm{CO}_{2}$ and $\mathrm{O}_{2}$ (overall $\approx 90 \%$ of its content) in the transition to the circular economy (CE) model in Europe [22,23]. The main issue in the operation of municipal waste landfills is the emission of two gases-i.e., $\mathrm{CH}_{4}$ and $\mathrm{CO}_{2}$-which are also the basic greenhouse gases [24,25]. Current findings in the field of $\mathrm{CH}_{4}$ emissions from landfills does not exhaust the topic due to their local conditions leaving a gap to fill—the undertaken research aims to supplement the knowledge in this area.

In response to the growing demand for energy, a part of $\mathrm{CH}_{4}$ generated in landfills is recovered in an organized manner and subsequently used for power production as a source of renewable energy - e.g., in cogeneration plants (Combined Heat and Power; CHPs). The remaining unrecognized amount of $\mathrm{CH}_{4}$ accounts for fugitive emissions from the landfill surface to the atmosphere along with carbon dioxide in biogas [26]. It seems that the use of renewable energy sources (including landfill gas) is an alternative to improve the energy balance of individual countries with the depletion of fossil fuel resources [27]. The diversification of energy generation sources also applies to the other types of biogas (not only LFG), as part of energy policies adopted by individual countries. In terms of municipal management, biogas generated from municipal sewage sludge in a sewage treatment plant can be applied as a source of renewable energy, not only for the production of electricity and heat in the cogeneration process, but also, e.g., as a gaseous fuel $\left(\mathrm{bioCH}_{4}\right)$ after the conversion of biogas to bioCH $\mathrm{C}_{4}$ - e.g., for motor vehicle engines [28]. Therefore, a justified need to search for highly effective methods of removing the contaminants from water and wastewater has been recognized [29]. Unfortunately, before the conversion to heat or electricity, the biogas must be cleaned of hydrogen sulfide $\left(\mathrm{H}_{2} \mathrm{~S}\right)$, a colorless, flammable and toxic odorant. The main issue related to high concentration of $\mathrm{H}_{2} \mathrm{~S}$ in biogas is its corrosive impact on some engine parts of cogeneration units and the formation of sulfur oxide $\left(\mathrm{SO}_{\mathrm{x}}\right)$ in the result of the combustion of $\mathrm{H}_{2} \mathrm{~S}$ [30].

In order to avoid the negative impact of waste treatment and neutralization processes on the natural environment, the introduction of a waste flow management system with a life cycle assessment (LCA) as a support of decision-making processes is justified [31]. Hence, the emission of greenhouse gases (including carbon dioxide) is being monitored permanently. The observed increment of $\mathrm{CO}_{2}$ emission enforced the search for process refinement, which not only reduces its emissions significantly, but also meets the economy-driven operational criteria of the installation [32]. Obviously, gas emission from landfill is related to both site conditions and environmental changes; however, few data are available that describe this linkage adequately [33].

The objective of the study was to perform a parametric analysis covering the production, emission and neutralization of $\mathrm{CH}_{4}$ in a real facility. In order to estimate the potential $\mathrm{CH}_{4}$ production in a waste deposit and the amount of the $\mathrm{CH}_{4}$ emission, the First Order Decay Model was utilized, which is based on Intergovernmental Panel on Climate Change (IPCC) methodology. In fact, the results of tests, measurements and operational data of the landfill were implemented as the input model data. The model findings proved that gas is produced in the landfilled waste deposit, therefore its collection and neutralization are required. Unfortunately, the performed calculations showed a pretty low efficiency of gas recovery in the result of low capacity of the operating passive degassing installation in relation to the total $\mathrm{CH}_{4}$ production in the waste deposit. The performed cluster analysis might be valuable in adapting the existing wells to their prospective use in the active degassing installations.

\section{Materials and Methods}

\subsection{Case Study Description}

The object of the research involves a municipal waste landfill located in the south of Poland, with an area of approx. 2.25 ha and a capacity of approx. 480 thousand $\mathrm{m}^{3}$. The landfill has a natural 
sealing from the ground with an insulating material and additionally with Polyethylene High-Density (PEHD) foil. This is equipped with an under-foil drainage system for groundwater and an over-foil drainage system for leachate, respectively. The leachates from the landfill are treated and discharged into a sanitary sewage system located near the landfill. The landfill stores municipal waste after mechanical treatment in the amount of about 25 to 30 thousand Mg/year. During the research period, the landfill was in its ninth year of operation-it was filled to $\approx 50 \%$ (percent) containing mainly wastes after mechanical treatment with average content (Total Organic Carbon) TOC $=0.061$. In order to capture biogas, at the construction stage of the landfill, a passive degassing installation was made which consisted of 9 vertical degassing wells, each with an individual gas flare. Under its own pressure, landfill gas (LFG) is transported to each flare, where the thermal neutralization of $\mathrm{CH}_{4}$ takes place without energy recovery.

The passive degassing installation was designed to capture $\mathrm{CH}_{4}$ (an important component of landfill gas), which is formed spontaneously along with carbon dioxide in landfills via anaerobic decomposition of organic matter. The process of landfill gas formation is influenced by a number of internal and external factors, including waste quality and moisture, temperature, $\mathrm{pH}$, anaerobiosis, nitrogen content, the degree of waste compaction, alkalinity and the presence of microorganisms, respectively, amongst others. In the processes of biochemical transformations in the waste deposit, organic components are subjected to hydrolysis, and subsequently the participation of initially aerobic bacteria (later mainly with anaerobic bacteria) waste is decomposed into organic acids, and finally into gases: $\mathrm{CH}_{4}$ and $\mathrm{CO}_{2}[34,35]$. The mass of coal that can be biologically converted to $\mathrm{CH}_{4}$ per ton of mixed municipal waste under the anaerobic conditions of a landfill is $\approx 160 \mathrm{~kg}$.

The gas generated in the waste deposit is a mixture of $\mathrm{CH}_{4}, \mathrm{CO}_{2}, \mathrm{O}_{2}, \mathrm{~N}_{2}$ and other compounds, containing mainly carbon, sulfur and chlorine derivatives. The biogas density is lower compared to the air density $\left(1.293 \mathrm{~kg} \cdot \mathrm{m}^{-3}\right.$ under normal conditions), which has a significant impact on fugitive emissions from the landfill. The monitoring performed confirms the presence of the above-mentioned gases within the following ranges: $\mathrm{CH}_{4} 36.2-49.2 \%, \mathrm{CO}_{2} 24.3-34.5 \%, \mathrm{O}_{2}, 1.8-6.1 \%$ and $\mathrm{N}_{2} 14.1-32.8 \%$, respectively. An active degassing system is currently a standard for this type of landfills, where gas recovered from the landfill deposit via a suction pipe is used for energy generation purposes [36,37].

\subsection{Research on the Morphological Composition of Waste}

The obtained test findings allow one to determine the content of organic carbon in the deposited waste. Moreover, the test results will constitute input data for the IPCC model in order to estimate the potential production of $\mathrm{CH}_{4}$ in the waste deposit.

The laboratory sample (weighing approximately $5 \mathrm{~kg}$ ) was collected in compliance with the requirements of the standard PN-EN 14899 (Polish norm in English version): 2006 with reference to waste sample collection for laboratory tests. Then, the sample was separated into two fractions using a sieve: fraction No. 1 with particle size $<10 \mathrm{~mm}$ and fraction No. 2 with particle size $\geq 10 \mathrm{~mm}$.

Additionally, individual components were selected from the fraction remaining on the sieve including: food waste of plant origin, food waste of animal origin, paper and cardboard waste, plastic waste, waste textile materials, glass waste, metal waste, other organic and mineral waste as well. All selected components from fractions No. 1 and No. 2 were weighed with an accuracy of $0.5 \mathrm{~g}$. The determination of the morphological composition of municipal solid waste was conducted following the standard PN-EN 15002: 2015-07. The percentage content of fraction No. 1 and the individual components of fraction No. $2\left(X_{n}\right)$ are expressed as a percentage quantity according to Formula (1):

$$
X_{n}=\frac{m_{w}}{m} \times 100 \%
$$

where:

$m_{w}$-mass of the individual waste components,

$m$-mass of the sample collected for examination. 
The results of the tests on the morphology of landfilled waste are reported in Table 1.

Table 1. Morphological composition of waste.

\begin{tabular}{cccc}
\hline No. & Component Name of Waste Fraction & Characteristics of Component & $\begin{array}{c}\text { Content of Individual } \\
\text { Components, } \%\end{array}$ \\
\hline 1. & Fraction $<10 \mathrm{~mm}$ & Remains from the mechanical treatment of waste & 39.3 \\
2. & Food waste of plant origin & Remains of plant substances generated during meal preparation & 3.1 \\
3. & Paper and cardboard waste & Remains of paper and cardboard products & 6.6 \\
4. & Plastic waste & Remains of plastic products & 13.1 \\
5. & Textile waste & Remains of products made of wool, cotton, linen and chemical fibers & 4.8 \\
6. & Glass waste & Remains of glass products and glass cullet & 7.5 \\
7. & Metal waste & Remains of products made from all types of metal and metal scrap & 0.5 \\
8. & Other organic waste & Organic waste remaining after the selection of components $1 \div 5$ & 6.3 \\
9. & Mineral waste & Mineral waste remaining after the selection of components $5 \div 6$ & 18.8 \\
\hline
\end{tabular}

\subsection{Measurements of Landfill Gas}

A passive degassing installation with 9 vertical wells was in operation during the research at the landfill site. Based on the natural pressure difference, the generated biogas was burnt in individual flares installed on each well without energy recovery. Each gas flare consists of a pipe supplying gas from the degassing well, manual shut-off/control valve, combustion chamber and gas sampling point, respectively. The measurements of biogas parameters were performed before the inflow to each flare four times a month for the period of one year (from January 1 to December 31) in the ninth year of landfill operation. In the course of the research, 434 samplings of biogas parameters were made for all wells. The measurements of the gas composition, the neutralization and $\mathrm{CH}_{4}$ emission as well as the parameters of the degassing installation were subjected to statistical analysis using the Statistica program ver. 13.3 by TIBCOI Software Inc., Palo Alto, CA, USA [38]. Characteristic values were determined with reference to the above-mentioned indicators, and the correlations of the variables with scatterplots, variability plots and cluster analysis were performed as well. The concentration and flow of the landfill biogas were measured in line with the operative procedures based on the obtained accreditation. The emission of individual gases was calculated using the gas flow rate (made with an anemometer), the percentage contents of individual gases, the diameter of the degassing well, pressure, temperature and relative humidity of the biogas. The content of $\mathrm{CH}_{4}$ and $\mathrm{CO}_{2}$ was measured with a gas analyzer using the absorption of IR radiation, while the concentration of $\mathrm{O}_{2}$ was specified using the electrochemical method.

The percentage content and the amount of $\mathrm{CH}_{4}$ emissions are the input parameters to be implemented in the first-order decay model.

\subsection{Model of Emission and Production of $\mathrm{CH}_{4}$ in a Landfill}

In order to estimate the potential $\mathrm{CH}_{4}$ emission from the surface of a landfill in operation, the First Order Decay Model (IPCC Waste Model) was applied, based on the IPCC standard method for input parameters of a landfill [39]. The IPCC method allows one to estimate the annual amount of $\mathrm{CH}_{4}$ generation in a waste deposit and the amount of the gas emission as the fugitive emission from the landfill surface to the air [40]. It is assumed that the decomposable organic components contained in the waste decompose slowly over many years, generating $\mathrm{CH}_{4}$ and $\mathrm{CO}_{2}$ emissions, respectively. In order to estimate the potential production of $\mathrm{CH}_{4} \mathrm{~L}_{\mathrm{O}}$, Equation (2) was used based on the performed tests and measurements as follows:

$$
L_{O}=M C F \times D O C \times D O C_{F} \times F \times \frac{16}{12}\left[\mathrm{GgCH}_{4} / \mathrm{Gg}_{\mathrm{W}}\right]
$$

where:

$L_{O}$ - potential $\mathrm{CH}_{4}$ production $\left[\mathrm{GgCH}_{4} / \mathrm{Gg}\right.$ waste],

$\mathrm{MCF}-\mathrm{CH}_{4}$-correction factor (depending on the type of landfill),

$D O C_{F}$-fraction of carbon that eventually undergoes decomposition, 
$\mathrm{F}-\mathrm{CH}_{4}$-content by volume in the landfill gas,

DOC — carbon content in the biodegradable organic in a given year [ $\mathrm{GgC} / \mathrm{Gg}$ of waste].

The content of carbon in the biodegradable organic part deposited in the landfill in a specific year (DOC) was calculated according to Formula (3), which takes into account the morphological analysis of the waste deposited in the landfill in percentage content by mass:

$$
D O C=(0.4 \times A)+(0.17 \times B)+(0.15 \times C)+(0.3 \times D)[\mathrm{GgC} / \mathrm{Gg} \text { waste }]
$$

where:

A-waste such as paper, cardboard and textiles,

$B$-waste from parks, gardens and other organic waste, excluding food,

C-food waste,

$D$-wood and straw waste.

In order to estimate the potential volume of $\mathrm{CH}_{4}$ emission from the landfill surface, Equation (4) was applied regarding operational data of the landfill.

$$
E_{\mathrm{CH}_{4}}=\left[\left(M S W_{T} \times M S W_{M} \times L_{O}\right)-R\right] \times(1-\mathrm{OX})\left[\mathrm{Gg} \cdot \mathrm{y}^{-1}\right]
$$

where:

$E_{\mathrm{CH}_{4}}$ - potential volume of $\mathrm{CH}_{4}$ emission $\left[\mathrm{Gg} \cdot \mathrm{y}^{-1}\right]$,

$\mathrm{MSW}_{T}$ - total mass of municipal waste deposited in the landfill over a year [Gg],

$M S W_{M}$-a part of municipal waste collected from the landfill $\left[\mathrm{Gg} \cdot \mathrm{y}^{-1}\right]$,

$R$-the volume of $\mathrm{CH}_{4}$ from the landfill, recovered and neutralized in the landfill $\left[\mathrm{Gg} \cdot \mathrm{y}^{-1}\right]$,

$\mathrm{OX}-\mathrm{CH}_{4}$-oxidation index in soil or in the material covering the waste.

In the implemented IPCC Waste Model, the emission of $\mathrm{CH}_{4}$ from the landfill is at its highest a few years after the deposition, and then it gradually decreases until the carbon contained in the waste is broken down by bacteria. The method properly estimates the annual emission for landfills, where the quantity and morphology of the deposited waste are known and the morphology changes insignificantly within a few years [41].

\section{Results}

The morphology of the landfilled waste is examined once a year as part of the obligatory environmental monitoring. The morphology of the landfilled waste was scrutinized in the set the laboratory tests as reported in Table 1.

The analysis of the landfilled waste sample indicated the highest percentage of waste with a fine fraction $<10 \mathrm{~mm}(39.3 \%)$ composed of the remains after the mechanical treatment of waste on the sorting line. Mineral waste was the second type of waste with a percentage of $18.8 \%$. The remaining waste, including biodegradable waste, accounted for $41.9 \%$. In the group of waste containing the biodegradable fraction, the greatest share is paper and cardboard waste $(6.6 \%)$, then other organic waste $(6.3 \%)$ and textile waste $(4.8 \%)$. The percentages of these wastes show a low efficiency of the mechanical treatment process as well as the low level of source segregation in this region. The measurements of the landfill gas parameters collected from the operating passive degassing installation in nine vertical wells demonstrated that methanogenic processes are taking place in the waste deposit. The average monthly contents of the individual parameters of biogas measured at the inlet to the collective flare over a year are presented in Table 2. 
Table 2. Parameters of landfill biogas in gas flares.

\begin{tabular}{|c|c|c|c|c|c|c|c|c|}
\hline \multirow[t]{2}{*}{$\begin{array}{l}\text { Number of } \\
\text { Well/Flare }\end{array}$} & \multicolumn{4}{|c|}{$\begin{array}{l}\text { Percentage Content of Individual } \\
\text { Parameters in Biogas }\end{array}$} & \multirow{2}{*}{$\begin{array}{l}\text { Stream of Biogas } \\
\text { Volume in the Flare } \\
\qquad\left(\mathrm{Nm}^{3} \cdot \mathrm{h}^{-1}\right)\end{array}$} & \multirow{2}{*}{$\begin{array}{c}\text { Biogas Neutralized } \\
\text { in the Flare } \\
\left(\mathrm{Nm}^{3} \cdot \mathrm{y}^{-1}\right)\end{array}$} & \multirow{2}{*}{$\begin{array}{c}\mathrm{CH}_{4} \text { Neutralized } \\
\text { in the Flare } \\
\left(\mathbf{k g} \cdot \mathrm{h}^{-1}\right)\end{array}$} & \multirow{2}{*}{$\begin{array}{c}\text { Annual Volume of } \\
\text { Neutralized } \mathrm{CH}_{4} \text { in } \\
\text { the Flare } \\
\left(\mathrm{Mg} \cdot \mathrm{y}^{-1}\right)\end{array}$} \\
\hline & $\mathrm{CH}_{4}$ & $\mathrm{CO}_{2}$ & $\mathrm{O}_{2}$ & $\mathbf{N}_{2}$ & & & & \\
\hline $\mathrm{SO} 2$ & 46.6 & 29.8 & 3.1 & 20.3 & 5.4 & 47,304 & 1.81 & 15.87 \\
\hline $\mathrm{SO} 3$ & 45.6 & 25.2 & 3.7 & 24.8 & 4.3 & 37,668 & 1.77 & 15.53 \\
\hline $\mathrm{SO} 4$ & 44.5 & 28.2 & 4.3 & 22.5 & 4.5 & 39,420 & 1.44 & 12.63 \\
\hline SO5 & 48.4 & 33.2 & 2.5 & 15.6 & 5.2 & 45,552 & 1.81 & 15.87 \\
\hline SO8 & 36.2 & 24.3 & 6.1 & 32.8 & 3.1 & 27,156 & 0.81 & 7.08 \\
\hline SO9 & 47.8 & 31.3 & 2.2 & 18.3 & 4.3 & 37,668 & 1.48 & 12.96 \\
\hline
\end{tabular}

The measurements as well as calculations indicated that the annual average basic parameters of landfill biogas from vertical degassing wells were as follows: $\mathrm{CH}_{4} 44.69 \%, \mathrm{CO}_{2} 28.85 \%, \mathrm{O}_{2} 3.71 \%$ and $\mathrm{N}_{2}$ $22.47 \%$, respectively. Landfill biogas with a $\mathrm{CH}_{4}$ content of about $45 \%$ has an energy value $\approx 16 \mathrm{MJ} / \mathrm{m}^{3}$. The annual amount of landfill biogas from nine wells in the landfill in the year under consideration was $374.928 \mathrm{~m}^{3}$, and the amount of thermally neutralized $\mathrm{CH}_{4}$ was $125.3 \mathrm{Mg}$. In order to group the wells according to the gas parameters and their efficiency, a cluster analysis was performed on data stored in Table 2. In the cluster analysis (hierarchical tree), Ward's agglomeration method was selected, which uses the variance approach to estimate the distance between clusters [42]. Ward's method aims to minimize the sum of the squared deviations of any two clusters, which may be formed at any stage. As a measure of distance, the Euclidean metric was used with the individual distances calculated on the basis of the raw data. Figure 1 illustrates the results of hierarchical grouping of the wells in the form of a dendrogram.

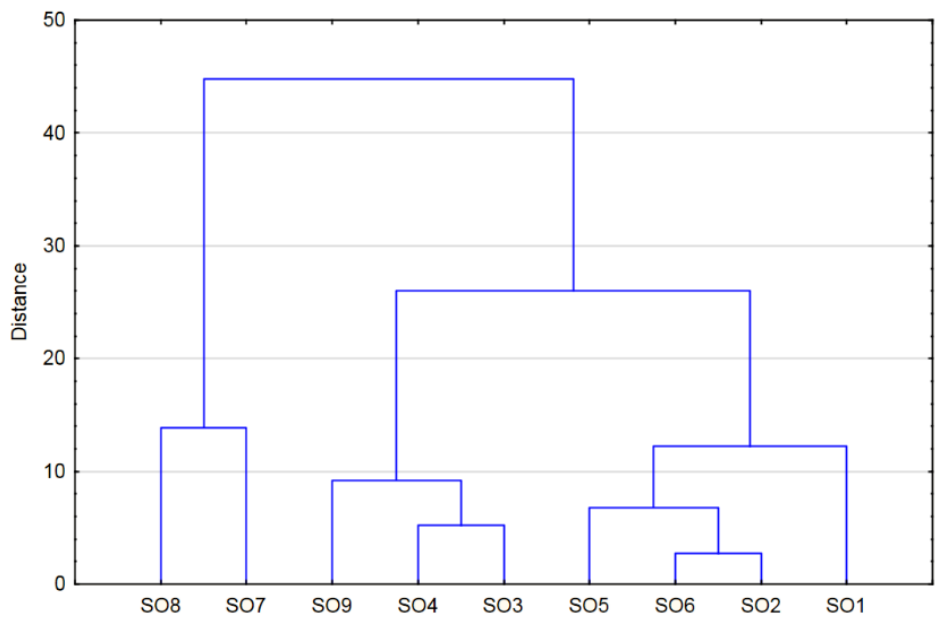

Figure 1. Dendrogram of cluster analysis.

The objects form clusters, where four main groupings can be distinguished. The first one contains a single object (SO1), the second and the third groups are composed of three objects, while the fourth one comprises two objects (SO7, SO8). The shortest distance in the second cluster is represented by the objects $\mathrm{SO} 6$ and SO2, mainly due to the fact that they are characterized by comparable parameters for all eight variables. A single SO1 object differs in parameters from the remaining ones-it is assigned to a binary tree with similar characteristics.

The generated biogas from the waste deposit wells is burnt in nine individual flares. Figure 2 illustrates the parameters of biogas in well SO1, which exhibits the highest parameters of $\mathrm{CH}_{4}$ and biogas stream. The average annual content of $\mathrm{CH}_{4}$ in the biogas was $49.2 \%$, with the biogas yield of $54.312 \mathrm{Mg} \mathrm{y}^{-1}$. Moreover, the SO1 well had also the lowest oxygen content $(1.8 \%)$. 


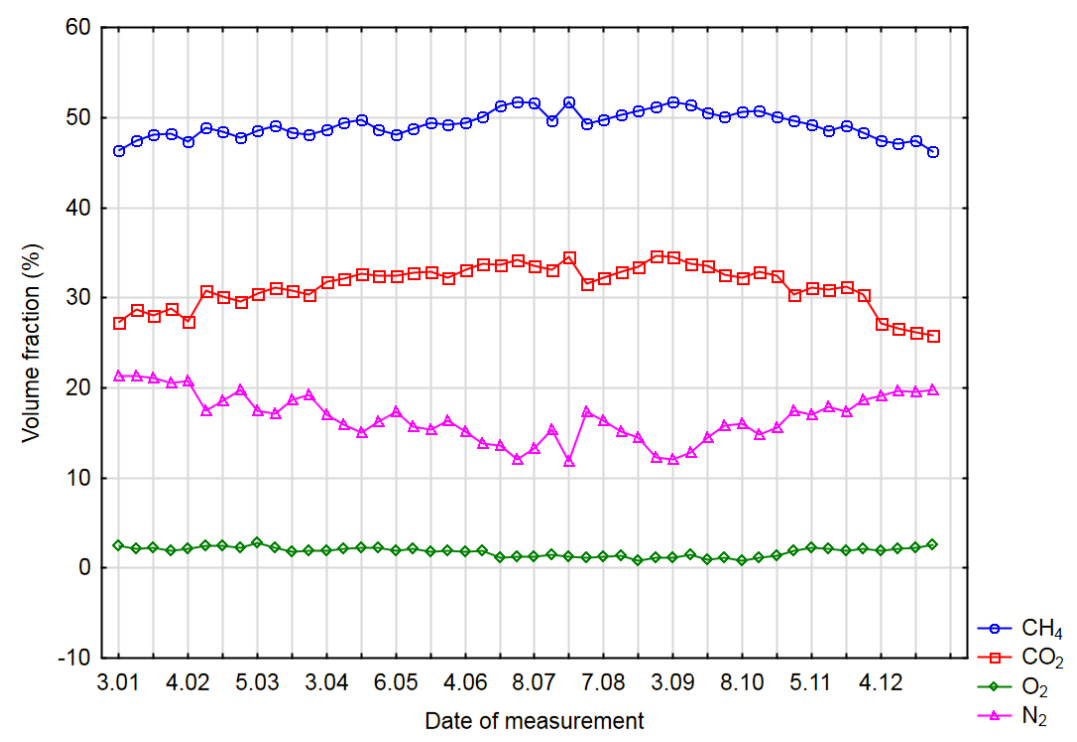

Figure 2. Biogas parameters in the single object (SO1) well.

On the other hand, the lowest values of parameters were found in the well SO8 (see Figure 2), with a $\mathrm{CH}_{4}$ content of $36.2 \%$, gas stream of $3.1 \mathrm{Nm}^{3} \cdot \mathrm{h}^{-1}$ and oxygen content of $6.1 \%$, respectively. The parameters of thermally neutralized biogas in individual gas flares indicate that the landfill is properly operated, including the degassing installation. The average annual capacity of passive degassing installation of the landfill is $4.76 \mathrm{~m}^{3}$ of biogas per hour.

Based on the morphology findings of the landfilled waste (see Table 1), the required parameters of waste reported in Table 3 were selected to calculate the content of carbon in the biodegradable organic part of the landfilled waste according to Formula (3).

Table 3. Percentage share of individual fractions of biodegradable waste.

\begin{tabular}{|c|c|c|}
\hline Waste Category & Waste Type & Value \\
\hline A-paper and textiles & $\begin{array}{c}\text { Remains of products } \\
\text { made of paper, cardboard and textiles }\end{array}$ & 0.114 \\
\hline $\begin{array}{l}\text { B-organic waste } \\
\text { except for food }\end{array}$ & $\begin{array}{c}\text { Organic waste from parks } \\
\text { and gardens }\end{array}$ & 0.063 \\
\hline $\begin{array}{l}\mathrm{C} \text {-waste made up } \\
\text { of food }\end{array}$ & $\begin{array}{c}\text { Remains of plant substances generated during } \\
\text { preparation of meals }\end{array}$ & 0.031 \\
\hline D—wood and straw & Not found & 0 \\
\hline
\end{tabular}

Due to the fact that in the waste morphology tests wood or straw waste were not identified, category $\mathrm{D}$ was ignored in further calculations. The content of carbon in the biodegradable organic part landfilled in the investigated year (DOC) was calculated based on Formula (3), which takes into account the morphological analysis of the landfilled waste in percentage content by mass as follows:

$$
D O C=(0.4 \times 0.114)+(0.17 \times 0.063)+(0.15 \times 0.031)=0.061[\mathrm{GgC} / \mathrm{Gg} \text { waste }]
$$

The findings of the waste morphological composition were implemented into the mathematical model. In consequence, the content of carbon in the biodegradable organic part DOC was calculated with a value of 0.061 [GgC/Gg of waste]. In order to estimate the potential amount of $\mathrm{CH}_{4}$ produced in the waste deposit, Equation (2) was used. The following input values for the model were used: 
a. $\mathrm{MCF}-\mathrm{CH}_{4}$ correction factor (depending on the type of landfill); the value was adopted at 1 . Following the IPCC guidelines, it is recommended that, for organized landfills with sealing and a waste transfer system, waste is thickened with a compactor,

b. $\quad D_{F}$ - carbon fraction, which ultimately undergoes decomposition; the value 0.5 (weight fraction) was adopted following the IPCC recommendations,

c. F-volumetric content of $\mathrm{CH}_{4}$ in the landfill gas; the value adopted on the basis of actual measurements as an annual average, amounting to $44.69 \%$-i.e., 0.447 ,

d. DOC — carbon content in the biodegradable organic part of the landfilled waste in a given year was calculated as follows:

$$
L_{O}=1 \times 0.061 \times 0.5 \times 0.447 \times \frac{16}{12}=0.018\left[\mathrm{GgCH}_{4} / \mathrm{Gg}_{\mathrm{W}}\right]
$$

The potential production of $\mathrm{CH}_{4}$ in the waste deposit from one deposited $\mathrm{Gg}$ of the waste was $0.018 \mathrm{Gg}$ in the investigated landfill (1 kilogram $[\mathrm{kg}]=1 \times 10^{-6}$ gigagram $\left.[\mathrm{Gg}]\right)$.

In order to estimate the potential emission of $\mathrm{CH}_{4}$ from the landfill, Equation (4) was used and the following input values for the model were implemented:

a. $M_{S} W_{T}$-total mass of municipal waste deposited in the landfill during the year based on operational data; adopted at $31.21[\mathrm{Gg}]$,

b. $M S W_{M}$ - the waste collected or extracted from the landfill; 0 was adopted since such a case did not occur,

c. $\mathrm{R}$-the amount of $\mathrm{CH}_{4}$ generated in the landfill and neutralized in a collective flare based on the measurements; value of $0.1253\left[\mathrm{Gg} \cdot \mathrm{y}^{-1}\right]$ was adopted,

d. OX- $\mathrm{CH}_{4}$ oxidation index in the soil or in the material covering the waste, which reflects the amount of $\mathrm{CH}_{4}$ oxidized in the soil or in other material covering the waste. For surface-sealed landfills with a material enabling the migration of oxygen (e.g., soil, compost); set at 0.1 according to the IPCC guidelines.

$$
E_{\mathrm{CH}_{4}}=[(31.20 \times 0.018)-0.125] \times(1-0.1)=0.393\left[\mathrm{Gg} \cdot \mathrm{y}^{-1}\right]
$$

The estimated amount of $\mathrm{CH}_{4}$ emissions $E_{\mathrm{CH}_{4}}$ from the landfill surface, reduced by the amount of $\mathrm{CH}_{4}$ neutralized in the collective flare and by $\mathrm{CH}_{4}$ oxidation in the soil was $393.1 \mathrm{Mg}$ of $\mathrm{CH}_{4}$ per year.

Based on the theoretical calculations, the annual amount of $\mathrm{CH}_{4}$ production from landfilled waste was estimated at level of $561.78\left[\mathrm{MgCH}_{4} \mathrm{y}^{-1}\right]$. The adopted parameters allowed us to calculate the efficiency of passive degassing of the landfill installation according to Formula (5).

$$
\eta_{g r s}=\frac{P_{\mathrm{CH}_{4}}-E_{\mathrm{CH}_{4}}-\mathrm{O}_{\mathrm{CH}_{4}}}{P_{\mathrm{CH}_{4}}} \times 100 \%
$$

where:

$\eta_{g r s}$-the efficiency of passive degassing installation [\%],

$P_{\mathrm{CH}_{4}}$-potential $\mathrm{CH}_{4}$ production $561.78\left[\mathrm{MgCH}_{4} \cdot \mathrm{y}^{-1}\right]$,

$E_{\mathrm{CH}_{4}}$-estimated $\mathrm{CH}_{4}$ emission from the landfill $393.1\left[\mathrm{MgCH}_{4} \cdot \mathrm{y}^{-1}\right]$,

$\mathrm{O}_{\mathrm{CH}_{4}}-\mathrm{CH}_{4}$ oxidized in the soil $43.38\left[\mathrm{MgCH}_{4} \cdot \mathrm{y}^{-1}\right]$,

$$
\eta_{g r s}=\frac{561.78-393.1-43.38}{561.78} \times 100 \%=22.3 \%
$$

The investigated landfill has the installation of passive degassing with an efficiency of $22.3 \%$. The remaining biogas that was neutralized in the flare accounts for fugitive emission from the landfill surface to the air. In fact, the efficiency of the degassing installation is relatively low to ensure the collection and neutralization of the remaining biogas, including $\mathrm{CH}_{4}$ produced in the landfill. 


\section{Discussion}

The conducted tests on the morphological composition of waste deposited in the investigated year indicated the presence of a biodegradable fraction made up by food waste of vegetable origin at $3.1 \%$, paper and cardboard waste at $11.4 \%$ and other organic waste (excluding food waste) at $6.3 \%$, respectively. The content of organic fraction in the analyzed sample is typical for waste subjected to a mechanical treatment. Based on the research findings, the calculated carbon content in the biodegradable organic part deposited in the landfill in a specific year (DOC) was $0.061[\mathrm{GgC} / \mathrm{Gg}]$. Higher values can be found elsewhere, but mixed wastes are mainly under consideration. Similar results were reported previously with $\mathrm{DOC}=0.08$ and $\mathrm{L}_{\mathrm{o}}$ at the level of 0.05 compared to 0.018 in this study [43]. The carbon content in the organic fraction of the landfilled waste can be reduced by the application of an additional mechanical treatment prior to a biological treatment process, where $56 \%$ reduction in biological activity was observed after 4 weeks of treatment $[44,45]$.

The storage of waste containing an organic fraction turns the landfill into a kind of bioreactor generating biogas with $\mathrm{CH}_{4}$. For $\mathrm{CH}_{4}$, which accounts for $44.69 \%$ of the biogas, anaerobic and methanogenic conditions prevail in the waste deposit [46]. The process of $\mathrm{CH}_{4}$ generation results from the presence of an organic fraction in the landfilled waste left over after the mechanical process; however, it is also dependent on oxygen content, temperature and humidity. Such a state is conducive to the generation of $\mathrm{CH}_{4}$ emissions from the landfill surface to the atmosphere, based on the implemented model and numerical simulations as presented previously [47]. A model to simulate the production of landfill gas and gas migration processes within and beyond the boundaries of landfills was proposed as well. It was proven that gas emissions from the landfill increase with the decrease in the atmospheric pressure- the numerical parameters confirmed the mechanisms of gas migration, as well as the other transfer-related processes. Obviously, the extraction of landfill gas and the subsequent neutralization of $\mathrm{CH}_{4}$ is a priority in curbing the negative effects (greenhouse gas) of climate change [48]. The options of gas management at the landfill site were investigated as well [49]. The acquisition of gas and its application for energy generation in Combined Heat and Power (CHP) systems or the conversion to bio- $\mathrm{CH}_{4}$, or its employment for the synthesis of gas with high $\mathrm{CH}_{4}$ through catalytic reforming were specified as the main goals [50]. The research on the content of biogas parameters conducted during the year demonstrated that the average annual $\mathrm{O}_{2}$ values were at the level of $3.71 \%$ and $\mathrm{CO}_{2}$ in the amount of $28.85 \%$. Such results bespeak the ongoing methanogenic phase and partial leakage of degassing wells at their above-ground part. Unfortunately, the applied passive degassing system does not provide optimal conditions for the collection of biogas and the neutralization of $\mathrm{CH}_{4}$ [51].

On the basis of the developed gas measurements, diagrams of the correlation between $\mathrm{CH}_{4}$, $\mathrm{CO}_{2}$ and $\mathrm{O}_{2}$ are provided. The diagram in Figure 3 depicts the dependence between $\mathrm{CH}_{4}$ and $\mathrm{O}_{2}$ in the landfill biogas generated in nine degassing wells (as annual average values).

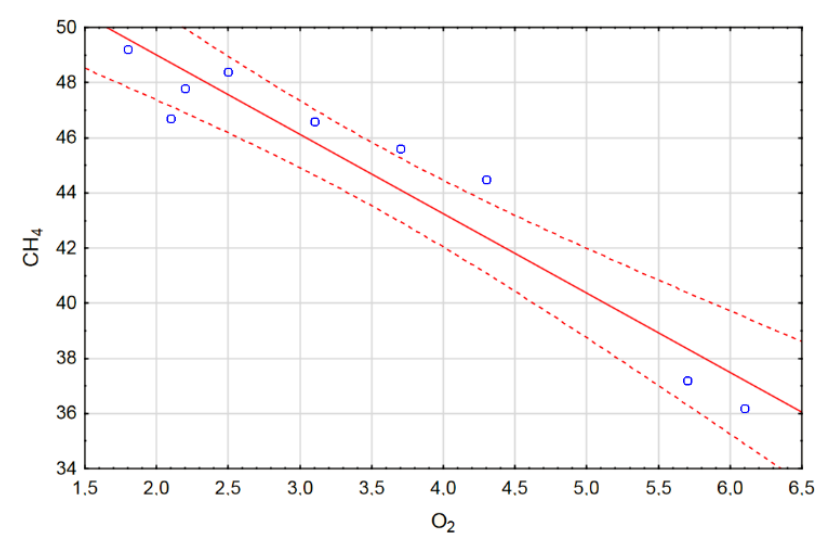

Figure 3. Scatterplot of the $\mathrm{CH}_{4}$ and $\mathrm{O}_{2}$ correlation. 
The scatterplot illustrates the negative correlation between $\mathrm{CH}_{4}$ and $\mathrm{O}_{2}$-the increase in the results of the variable $\mathrm{Y}\left(\mathrm{CH}_{4}\right)$ is accompanied by the decrease in the second variable $\mathrm{X}\left(\mathrm{O}_{2}\right)$, respectively. The least correlated points are the wells SO4 $(x=4.3 ; y=44.5)$ and SO6 $(x=2.1 ; y=46.7)$. The content of oxygen in the individual wells, ranging from 1.8 to $6.1 \%$, indicates that oxygen is being sucked into the landfill from outside-i.e., the gas wells are leaking. A similar mechanism of action was noticed previously with attention paid to the quality of the surface structure of the landfill with some fissures as well as cracks resulting from uneven settlement of waste and improper compaction of waste [52].

In the process of biogas generation in the landfilled waste deposit, the most methanogenic substances are mainly carbohydrates, fats and proteins; therefore, biogas with high $\mathrm{CH}_{4}$ content is generated. The higher the quotient $\mathrm{CH}_{4} / \mathrm{CO}_{2}$ the higher the energy value of the biogas. Figure 4 presents the graph of average annual values from nine wells with the correlation between $\mathrm{CO}_{2}$ and $\mathrm{CH}_{4}$ in the biogas collected at their outlet.

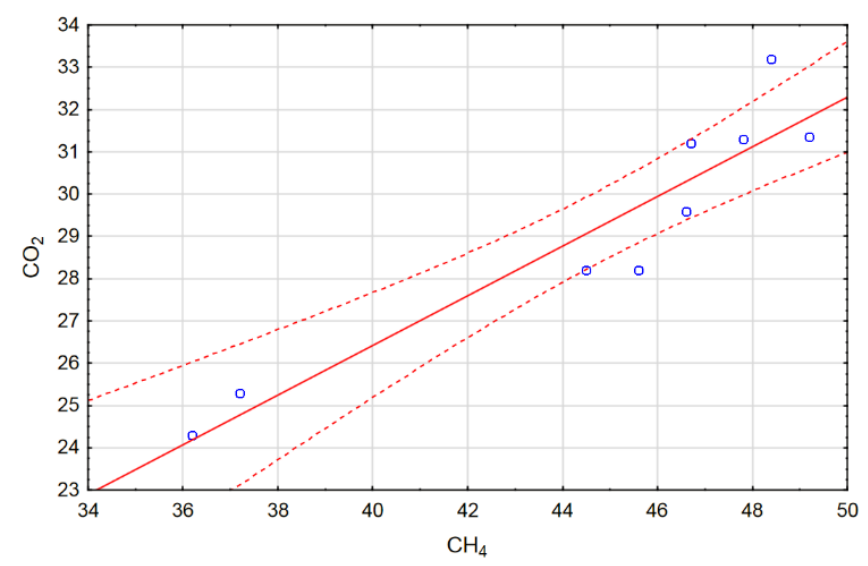

Figure 4. Scatterplot of the correlation between $\mathrm{CO}_{2}$ and $\mathrm{CH}_{4}$.

The scatterplot in Figure 4 shows the positive correlation between $\mathrm{CO}_{2}$ and $\mathrm{CH}_{4}$-the increase in the results of the variable $\mathrm{Y}\left(\mathrm{CO}_{2}\right)$ is accompanied by the increase in the second variable $\mathrm{X}\left(\mathrm{CH}_{4}\right)$. The least correlated points are wells SO3 $(x=45.6 ; \mathrm{y}=28.2)$ and SO5 $(\mathrm{x}=48.4 ; \mathrm{y}=32.3)$. The average annual value of $\mathrm{CH}_{4}$ in the wells ranged from 49.2 to $36.2 \%$, while the content of $\mathrm{CO}_{2}$ ranged from 34.5 to $24.3 \%$, respectively. The percentage composition of main gas bespeaks the ongoing methanogenic processes in the waste deposit. Similarly, the previous findings provided the mechanisms of biogas generation in the landfilled waste content of $\mathrm{CH}_{4}$ and $\mathrm{CO}_{2}$, indicating the large fluctuations that are related to the conditions of gas generation [53,54]. As a matter of fact, the following conclusions has been drawn: the composition of the produced gas may have large fluctuations, despite the fact that internal production rates are constant and that the extent of stoichiometric fluctuations will increase with the decrease in gas production [55]. This means that gas composition displays hysteresis, and it is hard to determine the degradation state of the object on the basis of gas composition measurements performed once or at rare time intervals. Methanogenic processes that take place in the waste deposit depend on both external and internal factors, respectively. Hence, the composition of the gas produced, in particular, in a landfill in operation will depend, inter alia, on the level of waste compaction that has a profound impact on the formation of anaerobic conditions as well as on the migration of water from precipitation.

It was found that the average annual stream of gas volume amounted to $4.76 \mathrm{~m}^{3} \cdot \mathrm{h}^{-1}$ for the passive degassing installation composed of nine individual vertical degassing wells with gas burnt in the individual flares. Hence, it possible to generate $374.928 \mathrm{~m}^{3}$ of gas from the waste deposit during the year, which enables the neutralization of 125.3 of $\mathrm{Mg} \mathrm{CH}_{4} \cdot \mathrm{y}^{-1}$. This allows the generation of approximately 525 MWh of electricity per year in the CHP system with an efficiency of about $40 \%$ [56]. Figure 5 presents the average annual $\mathrm{CH}_{4}$ content in the gas and the capacity of the degassing installation. 


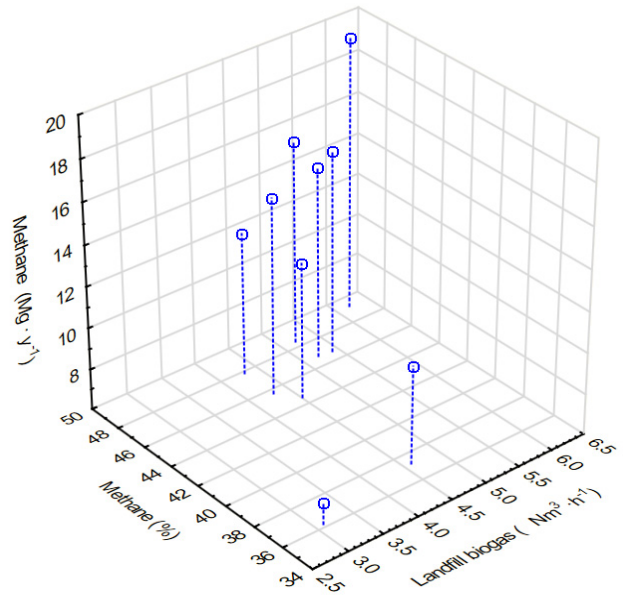

Figure 5. Capacity of the degassing installation.

In reality, the passive degassing system with individual flares is widely used in landfills as an intermediary solution to biogas combustion with energy recovery in CHP. The prevailing belief that flares burn landfill gas with 100\% efficiency was appealing, therefore further studies were conducted [57]. Hence, the numerical approach for emission specification was proposed to determine the gas composition in the flare, combustion conditions, throughput, wind speed, gas temperature, ambient temperature and atmospheric pressure, respectively. It was proven that the combustion efficiency drops sharply, while the content of $\mathrm{CH}_{4}$ in the gases drops below $50 \%$. For instance, with a $50 \%$ content of $\mathrm{CH}_{4}$ in landfill gas, the efficiency of its combustion in a flare is about $80 \%$, whereas when the $\mathrm{CH}_{4 \mathrm{~s}}$ content equal to $60 \%$ it approximates $92 \%$. Regarding the previous findings, the efficiency of landfill gas combustion conducted in nine flares is foreseen to oscillate at approximately $80 \%$. The use of passive carbon or biological lifting seems to be an appealing alternative to the use of individual flares for $\mathrm{CH}_{4}$ neutralization. The project of furnishing selected French landfills with a biomitigation system for the oxidation of $\mathrm{CH}_{4}$ has been described previously in detail [58].

The performed cluster analysis aims to distinguish the wells that have similar gas parameters and efficiencies in the context of building an active landfill degassing installation. This allows one to classify the wells according to their future operational applications, and to perform remedial actions (e.g., sealing) in order to limit the access of oxygen to the landfill gas. Moreover, the hierarchical grouping enables one to cluster the newly built wells with regard to the operational parameters and the parameterization of gas inlets, respectively.

The implemented IPCC first-order decay model is a supporting tool in the estimation of $\mathrm{CH}_{4}$ production and the potential emission from the landfill area. It is important to determine the input tests/measurements parameters, including both the percentage of $\mathrm{CH}_{4}$ in the biogas and the volume, that were neutralized (R). The practical application of the IPCC model confirmed that the actual data are important (not the estimated ones) [59]. For instance, the model demonstrates high sensitivity of $\mathrm{DOC}_{\mathrm{F}}$ and DOC parameters. Even though, a multitude of properties determine the gas landfill production, these variables are connected with empirical relationships; therefore, it is tough to retrieve accurate information regarding gas generation. It should be emphasized that accessible landfill data also contain sources of uncertainty that make them almost insufficient [60].

Hence, some input data, e.g., DOC, R, MSW $\mathrm{T}$ and F, were factual data-in this case the modeling results could be regarded as optimal. In fact, the parameter with a dominant impact on the final result is the content of carbon in the biodegradable organic part deposited in the landfill in a specific year (DOC). Component A (the residue of paper and cardboard products) was implemented in the model on the basis of the morphological composition of waste with a value of $11.4 \%$. Thus, the model generated the total production of $\mathrm{CH}_{4}$ at the level of $\mathrm{MgCH}_{4} \cdot \mathrm{y}^{-1}$, while a change of component $\mathrm{A}^{\prime} \mathrm{s}$ value by $1 \%$ upward will result in the increment of $\mathrm{CH}_{4}$ production $\mathrm{P}_{\mathrm{T}}$ by $9.8 \%$, and the enhancement 
of $\mathrm{E}_{\mathrm{CH} 4}$ emission by $12.2 \%$, respectively. Figure 6 illustrates the prediction of the quantity $\mathrm{A}=11.4 \%$ implemented into the model - the forecast raised by $1 \%$, i.e., $\mathrm{A}=12.4 \%$.

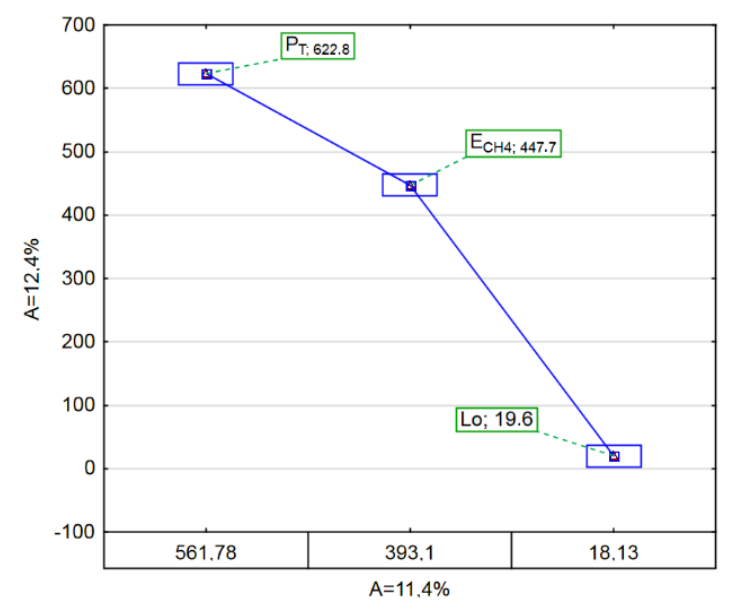

Figure 6. Dependence of modeling results on component A.

Moreover, a significant impact of $\mathrm{DOC}_{\mathrm{F}}$ parameter (carbon fraction ultimately subjected to decomposition) on the final result was observed. In fact, the value of $D C_{F}=0.5$ was implemented in the IPCC model. It was foreseen (see Figure 7) that the growth of $\mathrm{DOC}_{\mathrm{F}}$ by 0.1 results in the increment of $\mathrm{CH}_{4}$ production by $19.9 \%$ and the increase in emissions by $24.2 \%$, respectively.

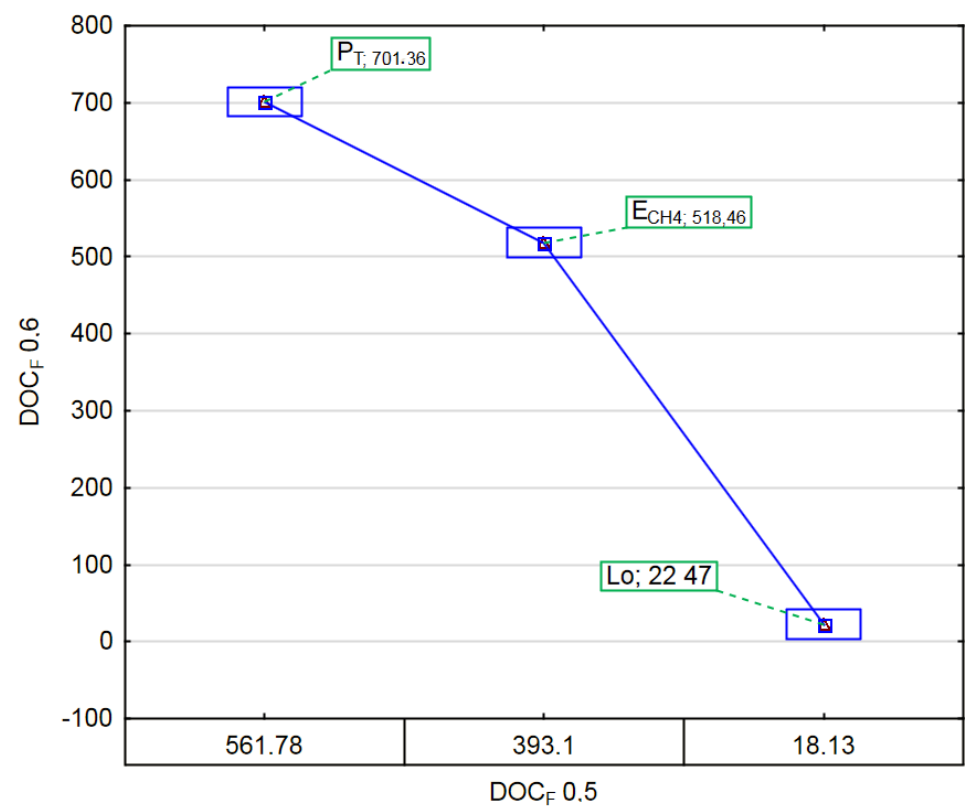

Figure 7. Prediction of $\mathrm{DOC}_{\mathrm{F}}$ parameter variations.

Similar dependence was observed previously with the fluctuation of $\mathrm{DOC}_{\mathrm{F}}$ in the range of $0.5 \div 0.77$. The former default value of $\mathrm{DOC}_{\mathrm{F}}=0.77$ was replaced by the current default value of 0.5 (recommended now by IPCC) [61]. The Swedish findings demonstrated that the model does not cover the arguments for $\mathrm{DOC}_{\mathrm{F}}<0.5$, while the $\mathrm{DOC}_{\mathrm{F}}$ for different waste fractions does not change considerably over longer time horizons [41]. Moreover, the results of $\mathrm{CH}_{4}$ emission modeling from landfills based on the variety of methodologies are available [62]. For instance, the comparison of $\mathrm{CH}_{4}$ emission approximated with the IPCC model versus the Land-GEM (Land Gas Emissions Model) indicated that the final outcome of the IPCC methodology was higher by $13.1 \%$, while the $\mathrm{CH}_{4}$ production was lower by $5.5 \%$, respectively. The estimation methods for the emission from the Legoli 
landfill (Tuscany, Italy) based on three different models (LandGem v3.02, IPCC 2006 and GasSim Lite 1.54) were compared with the findings of spot measurements performed in the landfill with the application of an accumulation chamber and the use of the Kriging method [40]. Not surprisingly, the comparison of the model-driven parameters with the empirical measurements demonstrated that the calculated variables do not reflect real working conditions of the surroundings-direct changes occurring in the landfill should be taken into consideration as well. In fact, the most convergent findings to experimental data were specified using the LandGem and IPCC models, respectively. A release of $\mathrm{CH}_{4}$, which is a potent greenhouse gas, can be reduced by in situ oxidation in the bioactive cover layer. Technically, the organic-rich porous materials (e.g., compost) are engaged in the process. Industrially engineered biocovers are characterized by the homogeneous particle sizes and an active microorganism consortium. In fact, the potential of $\mathrm{CH}_{4}$ oxidation in biocovers is strongly related to their chemical/physical characteristics, the age and seasonal variations of the cover material as well as the actual concentration of $\mathrm{CH}_{4}$ [36].

Based on the conducted parametric analysis, the efficiency at the level of $22.3 \%$ was revealed for the passive degassing installation composed of nine vertical degassing wells with individual flares. It should be emphasized that, even in modern landfills, it is not possible to reach $100 \%$ of $\mathrm{CH}_{4}$ efficiency in the degassing installation due to the fugitive emission [63]. On the other hand, an active degassing installation with gas used for energy generation can have an efficiency in the range of $67 \div 84 \%$. Of paramount significance is the use of impermeable transfer layers in landfills. Moreover, it was suggested to split the recovery installations of $\mathrm{CH}_{4}$ into two groups. The first one with an efficiency within the range of $14 \div 41 \%$, and the second one ranging from 48 to $78 \%$, respectively. Lower efficiency involves landfills, where the total production of $\mathrm{CH}_{4}$ is in the range of 229 to $705 \mathrm{~kg} \cdot \mathrm{h}^{-1}$ [41]. Unfortunately, the efficiency of presented gas recovery installation (22.3\%) does not ensure the optimal reduction in the level of $\mathrm{CH}_{4}$ emissions from the landfill since the remaining part of $\mathrm{CH}_{4}$ is unorganized (fugitive emission). As a matter of fact, the modernization or expansion of the landfill degassing system should be considered as well. In the case of the active installation construction, which sucks in gas from a waste deposit with an efficiency of, e.g., $75 \%$, and current $\mathrm{CH}_{4}$ production amounting to $561.78 \mathrm{MgCH}_{4} \cdot \mathrm{y}^{-1}$, the foreseen amount of $\mathrm{CH}_{4}$ neutralization should reach approximately $413.5 \mathrm{MgCH}_{4} \cdot \mathrm{y}^{-1}$. Hence, the optimal solution seems to be a use of $\mathrm{CH}_{4}$ for energy production in the cogeneration system for generating electricity or heat.

\section{Conclusions and Recommendations}

The main objective of the study was to perform a parametric analysis covering the production, emission and neutralization of $\mathrm{CH}_{4}$ in a real facility (a landfill). The results of the morphology studies of the landfilled waste demonstrated that the carbon content in the dissolved organic part deposited in the landfill was equal to 0.061 [GgC/Gg waste]. The measurements of gas parameters performed in the period of one year revealed that the average annual content of $\mathrm{CH}_{4}$ was $44.69 \%$, and $\mathrm{CO}_{2}$ was $28.85 \%$, respectively. Such gas parameters indicate that the landfill is in phase IV-the methanogenic one, where anaerobic (methanogenic) decomposition is dominant, characterized by a stabilized composition of transformation products. In order to estimate the potential of $\mathrm{CH}_{4}$ production in a waste deposit and the amount of its emission, the First Order Decay Model was used, which is based on the IPCC methodology. In fact, the results of tests, measurements and operational data of the landfill were implemented as the input model data. Hence, potential production $\mathrm{CH}_{4}$ in the waste deposit was determined at the level of $561.78\left[\mathrm{MgCH}_{4} \mathrm{y}^{-1}\right]$ and its fugitive emission from the landfill surface to the air was approximated to reach the amount of $393.1\left[\mathrm{MgCH}_{4} \mathrm{y}^{-1}\right]$. The negative correlation between $\mathrm{CH}_{4}$ and $\mathrm{O}_{2}$ was revealed, where the least correlated points are wells SO4 (x=4.3; $\mathrm{y}=44.5)$ and SO6 $(\mathrm{x}=2.1 ; \mathrm{y}=46.7)$, respectively. On the other hand, a positive correlation between $\mathrm{CO}_{2}$ and $\mathrm{CH}_{4}$ was noticed, where the least correlated points are wells SO3 $(\mathrm{x}=45.6 ; \mathrm{y}=28.2)$ and SO5 $(\mathrm{x}=48.4 ; \mathrm{y}=32.3)$. The total production of $\mathrm{CH}_{4}$ for an $\mathrm{A}$ value of $11.4 \%$ (the residue of paper and 
cardboard products) is estimated by the model at the level of $561.78 \mathrm{MgCH}_{4} \cdot \mathrm{y}-1$. A $1 \%$ increase in the A value will increase $\mathrm{P}_{\mathrm{T}} \mathrm{CH}_{4}$ production by $9.8 \%$ and $\mathrm{E}_{\mathrm{CH} 4}$ emissions by $12.2 \%$.

Not surprisingly, it is better to use the actual parameters as the input data into the methodology-the results are more reliable. The model findings proved that off-gas is produced in the landfilled waste deposit, therefore its collection and neutralization are required. As a matter of fact, the passive degassing installation in the landfill neutralized $\mathrm{CH}_{4}$ in the amount of $125.3\left[\mathrm{Gg} \mathrm{y}^{-1}\right]$ in nine flares. Unfortunately, the performed calculations showed a pretty low efficiency of gas recovery $(22.3 \%)$ in the result of the low capacity operating passive degassing installation in relation to the total $\mathrm{CH}_{4}$ production in the waste deposit. In consequence, it is recommended to install an active recovery system of biogas in a cogeneration unit to use off-gas as a source of energy. The use of $\mathrm{CH}_{4}$ neutralized in flares for energy purposes may result in the production of about $600 \mathrm{MWh}$ of electricity, of which the landfill will use about $40 \%$ for its own needs, and the surplus will be transferred to the power grid. It has been proven so far that the replacement of a passive installation with one that sucks in gas from a waste deposit increases the $\mathrm{CH}_{4}$ content in the landfill gas-this results in higher fuel value. Moreover, the performed cluster analysis might be valuable for adapting the existing wells to their prospective use in the active degassing installations. The produced energy from a renewable source can be used for the facility's own needs, and its surplus can be sent over to the external power grid or stored in the energy storage bank as well. Basically, the results indicate an unfavorable impact of the landfill on the air in consequence of mainly $\mathrm{CH}_{4}$ emissions, therefore the implementation of technology limiting this phenomenon in the first place, and ultimately the need to limit the storage of waste containing biodegradable fractions is necessary.

The proposed methodological approach can be used in landfills with similar technical solutions and comparable parameters of $\mathrm{CH}_{4}$ and gas stream, respectively. Moreover, the described procedure can be helpful to diagnose the current state of landfill and forecast the potential gas production as well as provide recommendations for more effective technical solutions. The research results are in line with the principles of sustainable development, including development through the exchange of scientific and technological knowledge, as well as the dissemination and transfer of new technologies. The proper functioning of the waste management system in the region must take into account the technical, environmental, economic and social objectives. The impact of waste neutralization technology on the natural environment is influenced not only by technological solutions, but also by the location and the so-called background conditions or the existing state.

The rapid intensification of cooperation between industry and academia is urgently needed in the field of emission and neutralization of methane from a municipal landfill.

Author Contributions: J.C., V.K., A.G., K.G., A.B., M.P. and K.B.-conceptualization, methodology, investigation, formal analysis, article writing and editing, data curation. All authors have read and agreed to the published version of the manuscript.

Funding: This research received no external funding.

Acknowledgments: The authors would like to thank the anonymous reviewers for their helpful comments.

Conflicts of Interest: The authors declare no conflict of interest.

\section{References}

1. UN. The Sustainable Development Goals Report. Available online: https://unstats.un.org/sdgs/report/2019/ The-Sustainable-Development-Goals-Report-2019.pdf (accessed on 21 November 2020).

2. Morrissey, A.J.; Browne, J. Waste management models and their application to sustainable waste management. Waste Manag. 2004, 24, 297-308. [CrossRef] [PubMed]

3. Pleissner, D.; Demichelis, F.; Mariano, S.; Fiore, S.; Navarro Gutiérrez, I.M.; Schneider, R.; Venus, J. Direct production of lactic acid based on simultaneous saccharification and fermentation of mixed restaurant food waste. J. Clean. Prod. 2017, 143, 615-623. [CrossRef]

4. Wojnicz, M.; Anielak, A.M. Kinetics of dairy wastewater treatment in the SBR system. Arch. Environ. Prot. 2010, 36, 27-37. 
5. Pavlas, M.; Dvořáček, J.; Pitschke, T.; Peche, R. Biowaste Treatment and waste-to-energy-Environmental benefits. Energies 2020, 13, 1994. [CrossRef]

6. Ng, K.S.; Yang, A.; Yakovleva, N. Sustainable waste management through synergistic utilisation of commercial and domestic organic waste for efficient resource recovery and valorisation in the UK. J. Clean. Prod. 2009, 227, 248-262. [CrossRef]

7. Indrawan, N.; Simkins, B.; Kumar, A.; Huhnke, R.L. Economics of distributed power generation via gasification of biomass and municipal solid waste. Energies 2020, 13, 3703. [CrossRef]

8. Ferrer-Martí, L.; Ferrer, I.; Sánchez, E.; Garfí, M. A multi-criteria decision support tool for the assessment of household biogas digester programmes in rural areas. A case study in Peru. Renew. Sustain. Energy Rev. 2018, 95, 74-83.

9. López-Gómez, J.P.; Alexandri, M.; Schneider, M.; Latorre-Sánchez, M.; Lozano, C.C.; Venus, J. Organic fraction of municipal solid waste for the production of L-lactic acid with high optical purity. J. Clean. Prod. 2019, 247, 119165-119173. [CrossRef]

10. Vlachokostas, C.; Achillas, C.; Agnantiaris, I.; Michailidou, A.V.; Pallas, C.; Feleki, E.; Moussiopoulos, N. Decision support system to implement units of alternative biowaste treatment for producing bioenergy and boosting local bioeconomy. Energies 2020, 13, 2306. [CrossRef]

11. Ryu, C.; Shin, D. Combined heat and power from municipal solid waste: Current status and issues in South Korea. Energies 2013, 6, 45. [CrossRef]

12. Lokesh, K.; Ladu, L.; Summerton, L. Bridging the gaps for a 'circular' bioeconomy: Selection criteria, bio-Based value chain and stakeholder mapping. Sustainability 2018, 10, 1695. [CrossRef]

13. Anielak, A.M.; Piecuch, T. Comparison of dewatering with pressure filtration and centrifugal filtration. Chem. Technik. 1987, 39, 101-103.

14. Liikanen, M.; Havukainen, J.; Viana, E.; Horttanainen, M. Steps towards more environmentally sustainable municipal solid waste management-A life cycle assessment study of São Paulo, Brazil. J. Clean. Prod. 2018, 196, 150-162. [CrossRef]

15. Połomka, J.; Jędrczak, A. RDF from compost-like-output's produced in the MBT installation in the case of Marszów, Poland. Energies 2020, 13, 4353. [CrossRef]

16. Mazzanti, M.; Zoboli, R. Municipal waste Kuznets curves: Evidence on socio-economic drivers and policy effectiveness from the EU. Environ. Resour. Econ. 2009, 44, 203-230. [CrossRef]

17. Przydatek, G. Multi-indicator analysis of the influence of old municipal landfill sites on the aquatic environment: Case study. Environ. Monit. Assess. 2019, 191, 773-792. [CrossRef]

18. Rybicki, S.M.; Wiewiórska, I. Minimizing the concentration of aluminum in tap water after coagulation. Przemyst Chem. 2017, 96, 1719-1722.

19. Wysowska, E.; Kudlik, K.; Kicińska, A. Bacteriological health threats to water in home wells. Arch. Environ. Prot. 2020, 46, 21-34.

20. Wysowska, E.; Kicińska, A.; Nikiel, G. Analysis of natural vulnerability of groundwater intakes to migration of surface pollutants based on a selected part of the Dunajec river basin. Pol. J. Environ. Stud. 2020, 29, 2925-2934. [CrossRef]

21. Spyridi, D.; Vlachokostas, C.; Michailidou, A.V.; Sioutas, C.; Moussiopoulos, N. Strategic planning for climate change mitigation and adaptation: The case of Greece. Int. J. Clim. Chang Strateg. Manag. 2015, 7, $272-289$. [CrossRef]

22. Brindley, T. Landfill Gas—Industry Code of Practice: The Management of Landfill Gas; Environment Services Association: London, UK, 2012; Available online: http://www.esauk.org/reports_press_releases/esa_reports/ LandfillgasICoP2012web.pdf (accessed on 16 August 2020).

23. Smol, M.; Avdiushchenko, A.; Kulczycka, J.; Nowaczek, A. Public awareness of circular economy in southern Poland: Case of the Malpolska region. J. Clean. Prod. 2018, 197, 1035-1045. [CrossRef]

24. Lee, U.; Han, J.; Wang, M. Evaluation of landfill gas emissions from municipal solid waste landfills for the life-cycle analysis of waste-to-energy pathways. J. Clean. Prod. 2017, 166, 335-342. [CrossRef]

25. Hoo, P.Y.; Hashim, H.; Ho, W.S. Opportunities and challenges: Landfill gas to bioCH4 injection into natural gas distribution grid through pipeline. J. Clean. Prod. 2018, 175, 409-419. [CrossRef]

26. Themelis, N.J.; Ulloa, P.A. CH4 generation in landfills. Renew. Energy 2007, 32, 1243-1257. [CrossRef]

27. Winquist, E.; Rikkonen, P.; Pyysiäinen, J.; Varho, V. Is biogas an energy or a sustainability product?-Business opportunities in the Finnish biogas branch. J. Clean. Prod. 2019, 233, 1344-1354. [CrossRef] 
28. Smol, M.; Włodarczyk-Makuła, M.; Skowron-Grabowska, B. PAHs removal from municipal landfill leachate using integrated membrane system aspect of legal regulation. Desalin. Water Treat. 2017, 69, 335-343. [CrossRef]

29. Ciuła, J.; Gaska, K.; Iljuczonek, Ł.; Generowicz, A.; Koval, V. Energy efficiency economics of conversion of biogas from the fermentation of sewage sludge to bioCH4 as a fuel for automotive vehicles. ACEE Archit. Civ. Eng. Environ. 2019, 12, 131-140.

30. Barbusiński, K.; Kalemba, K. Use of biological methods for removal of $\mathrm{H}_{2} \mathrm{~S}$ from biogas in wastewater treatment plants-A review. ACEE Archit. Civ. Eng. Environ. 2016, 9, 103-111. [CrossRef]

31. Turner, D.A.; Williams, I.D.; Kemp, S. Combined material flow analysis and life cycle assessment as a support tool for solid waste management decision making. J. Clean. Prod. 2016, 129, 234-248. [CrossRef]

32. Olejnik, T.P.; Sobiecka, E. Utilitarian technological solutions to reduce $\mathrm{CO}_{2}$ emission in the aspect of sustainable development. Probl. Ekorozw. Probl. Sustain. Dev. 2017, 12, 173-179.

33. Boltze, U.; de Freitas, M.H. Monitoring gas emissions from landfill sites. Waste Manag. Res. 1997, 15, 463-476. [CrossRef]

34. Ljungberg, S.A.; Meijer, J.E.; Rosqvint, H.; Martenss, S.G. Rapport SGS 204. Detection and quantification of CH4 from landfills leakage from landfills. Sven. Gasteklniskt Center 2009, 204, 1102-7371.

35. Spokas, K.; Bogner, J.; Chanton, J.P.; Morcet, M.; Aran, C.; Graff, C.; Moreau, Y.; Hebe, I. CH4 mass balance at three landfill sites: What is the efficiency of capture by gas collection systems? Waste Manag. 2006, 26, 516-525. [CrossRef] [PubMed]

36. Raco, B.; Battaglini, R.; Lell, M. Gas emission into the atmosphere from controlled landfills:an example from Legoli landfill (Tuscany, Italy). Environ. Sci. Pollut. Res. 2010, 17, 1197-1206. [CrossRef]

37. Di Maria, F.; Sordi, A.; Micale, C. Experimental and life cycle assessment analysis of gas emission from mechanically-biologically pretreated waste in a landfill with energy recovery. Waste Manag. 2013, 33, 2557-2576. [CrossRef]

38. TIBCOI Software Inc. Statistica; Version 13.3; TIBCOI Software Inc.: Palo Alto, CA, USA, 2017.

39. IPCC Guidelines for National Greenhouse Gas Inventories 2006, 5 (Waste). 2006. Available online: https://www.ipcc-nggip.iges.or.jp/public/2006gl/vol5.html (accessed on 2 September 2020).

40. Dimishkovska, B.; Berisha, A.; Lisichkov, K. Estimation of CH4 emissions from Mirash municipal solid waste sanitary landfill, Differences between IPPC 2006 and LandGEM Method. J. Ecol. Eng. 2019, 20, 35-41. [CrossRef]

41. Börjesson, G.; Samuelsson, J.; Chanton, J.; Adolfsson, R.; Galle, B.; Svensson, B. A national landfill CH4 budget for Sweden based onfield measurements, and an evaluation of IPCC models. Tellus B Chem. Phys. Meteorol. 2009, 61, 424-435. [CrossRef]

42. Joe, H.; Ward, J.H., Jr. Hierarchical grouping to optimize an objective function. J. Amer. Statist. Assoc. 1963, 58, 236-244.

43. Jigar, E.; Bairu, A.; Gesessew, A. Application of IPCC model for estimation of CH4 from municipal solid waste landfill. J. Environ. Sci. Water Res. 2014, 3, 52-58.

44. Rolewicz-Kalińska, A.; Lelicińska-Serafin, K.; Manczarski, P. The circular economy and organic fraction of municipal solid waste recycling strategies. Energies 2020, 13, 4366. [CrossRef]

45. Scaglia, B.; Confalonieri, R.; D'Imporzano, G.; Adani, G. Estimating biogas production of biologically treated municipal solid waste. Bioresour. Technol. 2010, 101, 945-995. [CrossRef] [PubMed]

46. Przydatek, G.; Ciagło, K. Assessment of the variability of the landfill gas composition captured on a used landfill. In Renewable Energy Sources: Engineering, Technology, Innovation; Wróbel, M., Jewiarz, M., Szlęk, A., Eds.; Springer Proceedings in Energy; Springer: Cham, Switzerland, 2020; pp. 775-785.

47. Nastev, M.; Therrien, R.; Lefebvre, R.; Gelinas, P. Gas production and migration in landfills and geological materials. J. Contam. Hydrol. 2001, 52, 187-211. [CrossRef]

48. Frasi, N.; Rossi, E.; Pecorini, I.; Iannelli, R. Methane oxidation efficiency in biofiltration systems with different moisture content treating diluted landfill gas. Energies 2020, 13, 2872. [CrossRef]

49. Beylot, A.; Villeneuve, J.; Bellenfant, G. Life cycle assessment of landfill biogas management: Sensitivity to diffuse and combustion air emissions. Waste Manag. 2013, 33, 401-411. [CrossRef] [PubMed]

50. Han, D.; Kim, Y.; Cho, W.; Baek, Y. Effect of oxidants on syngas synthesis from biogas over 3 wt \% $\mathrm{Ni}-\mathrm{Ce}-\mathrm{MgO}-\mathrm{ZrO}_{2} / \mathrm{Al}_{2} \mathrm{O}_{3}$ catalyst. Energies 2020, 13, 297. [CrossRef] 
51. Scheutz, C.; Kjeldsen, P.; Bogner, J.E.; De Visscher, A.; Gebert, J.; Hilger, H.A.; Huber-Humer, M.; Spokas, K. Microbial $\mathrm{CH} 4$ oxidation processes and technologies for mitigation of landfill gas emissions. Waste Manag. Res. 2009, 27, 409-455. [CrossRef]

52. Barański, A.; Bojanowicz-Bablok, A. Estimating the externalities of $\mathrm{CH} 4$ emission from municipal solid waste landfill: A case study. Environ. Prot. Nat. Res. 2014, 25, 11-16.

53. Kallistova, A.; Yu, M.V.; Kevbrina, M.V.; Nekrasova, V.K.; Glagole, M.V.; Serebryanaya, M.I.; Nozhevnikova, A.N. CH4 oxidation in landfill cover soil. Microbiology 2005, 74, 608-614. [CrossRef]

54. Eklund, B.; Anderson, E.G.; Walker, B.I.; Burrows, D.B. Characterization of landfill gas composition at the fresh kills municipal solid-waste landfill. Environ. Sci. Technol. 1998, 32, 2233-2237. [CrossRef]

55. Young, A. The effects of fluctuations in atmospheric pressure on landfill gas migration and composition. Water Air Soil Pollut. 1992, 64, 601-616. [CrossRef]

56. Vakalis, S.; Moustakas, K. Applications of the 3T method and the R1 formula as efficiency assessment tools for comparing waste-to-energy and landfilling. Energies 2019, 12, 1066. [CrossRef]

57. Pehme, K.M.; Orupõld, K.; Kuusemets, V.; Tamm, O.; Jani, Y.; Tamm, T.; Kriipsalu, M. Field study on the efficiency of a methane degradation layer composed of fine fraction soil from landfill mining. Sustainability 2020, 12, 6209. [CrossRef]

58. Willis, J.; Checkel, D.; Handford, D.; Shah, A.; Joiner, M. Flare Efficiency Estimator and Case Studies; Water Environment Research Foundation: Alexandria, VA, USA, 2013.

59. Bour, O.; Zdanevitch, I.; Huyard, A.; Akerman, A.; Lacour, G.; Chassagnac, T. Passive biomitigation of diff use landfill gas emissions on 12 French landfills: Return of experience on design criteria used. In Proceedings of the 15th International Waste Management and Landfill Symposium, Sardinia, Italy, 5-9 October 2015.

60. Mou, Z.; Scheutz, C.; Kjeldsen, P. Evaluation and application of site-specific data to revise the first-order decay model for estimating landfill gas generation and emissions at Danish landfills. J. Air Waste Manag. Assoc. 2014, 65, 686-698. [CrossRef] [PubMed]

61. Mohsen, R.A.; Abbassi, B. Prediction of greenhouse gas emissions from Ontario's solid waste landfills using fuzzy logic based model. Waste Manag. 2020, 102, 743-750. [CrossRef] [PubMed]

62. Bogner, J.; Matthews, M. Global CH4 emissions from landfills: New methodology and annual estimates 1980-1996. Glob. Biogeochem. Cycles 2003, 17, 1065-1083. [CrossRef]

63. Barlaz, M.A.; Jeff, P.; Chanton, J.P.; Green, R.B. Controls on landfill gas collection efficiency: Instantaneous and lifetime performance. J. Air Waste Manag. Assoc. 2009, 59, 1399-1404. [CrossRef] [PubMed]

Publisher's Note: MDPI stays neutral with regard to jurisdictional claims in published maps and institutional affiliations.

(C) 2020 by the authors. Licensee MDPI, Basel, Switzerland. This article is an open access article distributed under the terms and conditions of the Creative Commons Attribution (CC BY) license (http://creativecommons.org/licenses/by/4.0/). 